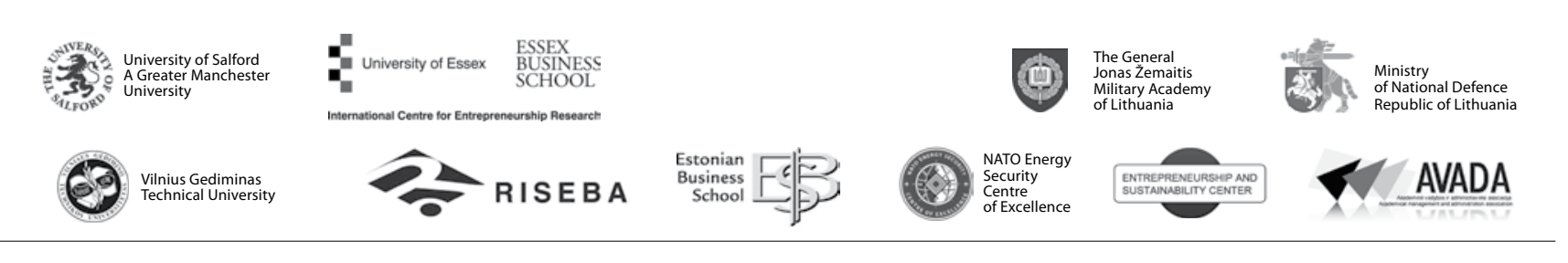

\author{
JOURNAL OF SECURITY AND SUSTAINABILITY ISSUES \\ ISSN 2029-7017 print/ISSN 2029-7025 online \\ 2017 June Volume 6 Number 4 \\ http://doi.org/10.9770/jssi.2017.6.4.(5)
}

\title{
NETWORK CAPITAL PHENOMENON AND ITS POSIBILITIES UNDER THE INFLUENCE OF DEVELOPMENT OF INFORMATION AND COMMUNICATION TECHNOLOGIES
}

\author{
Vladimir Menshikov ${ }^{1}$, Olga Lavrinenko ${ }^{2}$, Ludmila Sinica $^{3}$, Anastasiia Simakhova ${ }^{4}$ \\ 1,2,3, Daugavpils University, Vienības iela 13, Daugavpils, LV-5401, Latvia \\ ${ }^{4}$ Oles Honchar Dnipro National University, Dnipro, Ukraine \\ E-mails:1'vladimirs.mensikovs@du.lv; ${ }^{2}$ olga.lavrinenko@du.lv; \\ 3ludmila.sinica@gmail.com; ${ }^{4}$ simakhova_a@fme.dnulive.dp.ua
}

Received 10 December 2016; accepted 25 March 2017

\begin{abstract}
Network capital is a little explored phenomenon, but it is difficult to imagine the existence of man and society without networking effect. Network capital is a special type of social capital, its new branch in the e-society, the result of scientific and technical progress, in particular, the development of information and communication technologies (ICT). Network capital has a huge impact on the formation of modern society, accelerating and facilitating the development of globalization process and processes of global resource sharing and redistribution. Due to this positive influence, it blurs boundaries between global and local problems, creating new opportunities beyond the limitations of space or time, contributing to the economic development of enterprises at the local, regional and global level. Thereby becomes topical the necessity for a more efficient management of network capital, as well as the need to develop methods of its measurement and analysis. In the first part of the paper, authors examined the relevance of network capital phenomenon and generalized examples of its use in the modern e-society. In the second part of the article authors identified place of network capital in the context of aggregate capital, conducted a literature review, summarizing the main principles and concepts of network capital theory. The literature review showed that the role and possibilities of network capital development are poorly understood, a very small number of researches have been carried out on the subject and they do not present enough empirical analysis. The differences in terminology and interpretation of the phenomenon was revealed as well. In the third part of the article, authors analysed dynamics of the main ICT infrastructure indicators and indicators, which effect the development of network capital. The research helped to identify the main trends in network capital infrastructure changes over the past 10 years, as well as to ascertain the main problems and imbalances in its development. The analysis showed that between network capital and economic development of the country presents a very strong logarithmic dependence. At the end of the article authors presented conclusions on the work done. The paper is a preparatory base for further research in the field of network capital.
\end{abstract}

Keywords: network capital, network, networking, social capital, information and communication technology (ICT), information society, information economy, regional economy

Reference to this paper should be made as follows: Menshikov, V.; Lavrinenko, O.; Sinica, L. 2017. Network capital phenomenon and its posibilities under the influence of development of information and communication technologies, Journal of Security and Sustainability Issues 6(4): 585-604 http://doi.org/10.9770/jssi.2017.6.4.(5)

JEL Classifications: A14, R11, C10, J24

\section{Introduction}

Since time immemorial, people tend to join together to achieve common goals and improve their performance. Over time, the possibilities of cooperation expand, new methods of communication emerge, pace of technology development accelerates and takes place transformation of capital forms. The sociologist Endre Sik, who has significantly contributed to the study of network capital, writes: "In the course of transformation all other forms 
of capital (monetary, physical, human capital) were scarce and/or lost their value, hence trust and network capital became core assets, often the most crucial forms of capital to enable success in this mushrooming informal environment" (Sik 1994, p.54). Previously, communities were united by geography, but nowadays cooperation is based on common interests. At the new stage of history, in the age of information and computerization, it is appropriate to consider social capital in a new way and in a new context.

The development of technologies is rapidly changing modern economic processes at the micro and macro levels, automating and upgrading all areas of national economies. Along with the changes in production of goods and provision of services, information and communication technologies allow to erase geographical borders and distances, changing the idea of cooperation and collaboration, generating social networks and increasing the value of social capital. They create all the new tools for the transmission, exchange and storage of information at a distance, including the tools stimulating the creation of networks of interests: wikis, search engines, information aggregators, content advisors, groupware, mapping, tagging, meta tags, cloud collaboration. Virtual space and internet communities are developing - social networks, blogs and news portals, podcasting, RSS-feeds, etc. These changes in the methods of communication and cooperation bring fundamental modifications in the social and economic global processes, changing common and well-established concepts. These innovative changes in social processes are a strong incentive to promote the idea of network capital and endorse its analysis. Work in this area enables one to understand the nature of interaction, trust and cooperation in the new global digital environment.

\section{The topicality of network capital and its examples in the modern economy}

With innovative features of remote cooperation, new types of business and economic activities are developing. Communities and associations, connected by same interests, create social networks in the Internet environment (Allabouche et al. 2016; Samašonok et al. 2016; Prause 201; Fuschi, Tvaronavičienè 2016; Dlugoborskytė et al. 2015; Grubicka, Matuska 2015).

The development of network structure and technologies allows individuals to work in any company of the world without leaving their house. An excellent example of such cooperation is the freelance, or, in other words, self-employment like independent contractor. Specialists of different professions, who are able to carry out their work in electronic format or deliver it to another country, organize special online communities and use professional associations or websites to do work in digital environment. One of the most popular communities is Upwork service (former oDeck) and their statistics show that in early 20159.7 million freelancers and 3.8 million companies offering work were registered on the web service (Upwork 2015).

Another example is an outsourcing or, in other words, the possibility to transmit certain enterprise processes and functions to another organization. Outsourcing activity has become possible due to the development of technologies and social capital accumulation. Despite the fact that income from the final product belongs to the customer country, taxable administrative and personnel costs as well as a performer company's profit bring significant revenue to national economy. These types of cooperation are particularly relevant in times of shortage of skilled IT developers. In fact, this is an absolutely logical and natural process of the world resources redistribution (in this case of labour resources) only in the electronic environment and using distant cooperation opportunities. In this situation, real labour emigration does not occur and does not bring any significant changes to the global demography.

One more important example of a platform for networking is the professional social network Linked In, which allows finding the necessary business contacts on the Internet. If in the case of social networks like Facebook and Instagram, the main target is informal, friendly chat and other social purposes, then professional networks contribute to economic development, creating new possibilities for business cooperation. Besides, it offers a very interesting concept of contact search that allows you to find not only the representatives of certain professions and businesses, but also people with certain interests, hobbies, skills and so on. Thus, the formation of contacts becomes easier and faster, and that contributes to overall economic development through the accumulation of network capital. 
Surprising is also speed of social web networks development mentioned earlier - if in early 2009 the number of monthly active Facebook users worldwide was 197 millions, than at the beginning of 2016 this figure has risen to 1654 million ( 8 times). In turn, the numbers of LinkedIn members at the beginning of 2009 amounted to 37 million and in early 2016 this figure has increased by almost 12 times (433 million users) (Statista 2017). These findings very vividly illustrate the growing popularity of social networks in the digital space, allowing users to find contacts and communicate with other users outside their geographic and social proximity.

There are many examples of cooperation, built at the expense of network capital, including e-commerce, use of information and communication technologies for the performance of different professional duties, networking and e-government (the way of provision of information and public services in electronic environment).

The use of electronic services as a method of communication and networking may be observed on the example of the whole country. Estonia is one of the world leaders in terms of implementation and use of e-services in the daily life of inhabitants, enterprise operations and reporting, as well as a communication method with the government institutions, method of public services delivery and the innovative concept of "e-Residency". "E-residency offers to every world citizen a government-issued digital identity and the opportunity to run a trusted company online, unleashing the world's entrepreneurial potential. The main principles of e-Residency offer opportunities to establish an Estonian company online, conduct e-banking and remote money transfers, digitally sign documents and contracts, encrypt and transmit documents securely, administer the company from anywhere in the world and other functions." (Government Office of Estonia 2016). The statistics show that in October 2016 the opportunity to receive e-Residency in Estonia was taken by nearly 10 thousand people. This innovation brings a number of positive effects for the country. First of all this is a raise in capital and investments and an increase in economic potential. Moreover, it attracts skilled labour to the country and provides access to the global market of intellectual property. Estonian e-Residency is an excellent example of network capital, which erases boundaries and distance between two cooperating agents.

The relevance of the network capital threads confirm the data of search results for articles published from 1992 to 2016 in the abstract and citation dabase Elsevier's Scopus (Figure 1).

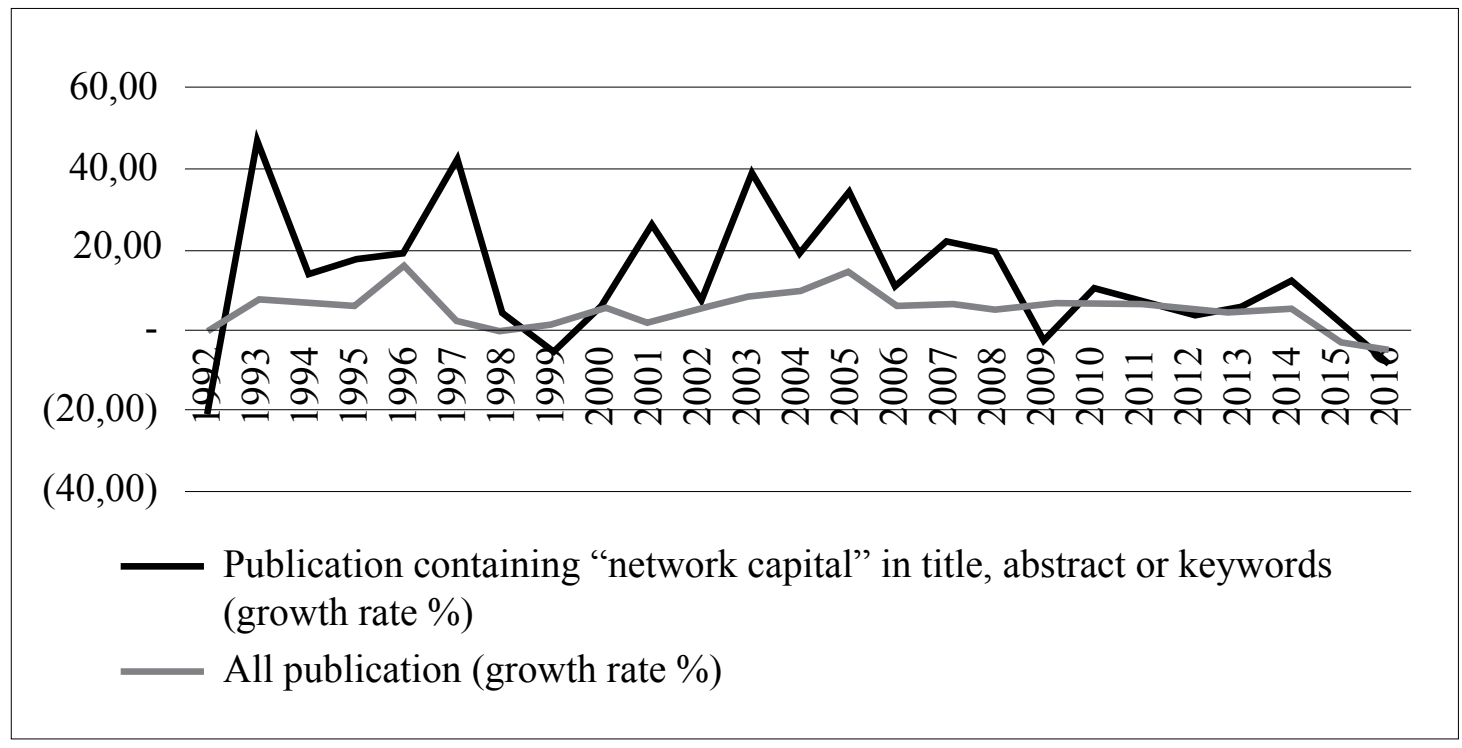

Fig. 1. Percentage change in the number of all publications and publications, which contain words "network capital" in the title, abstract or keywords, in the Scopus abstract and citation database from 1992 to 2016

Source: Elsevier B.V, Scopus abstract and citation database. Search result analyzer (2017), available: https://www.scopus.com/term/analyzer 
The graph shows the growth rate of all publications published in the database from 1992 to 2016, compared with a growth rate of publications, which contain words "network capital" in the title, abstract or keywords. The data was obtained by using the proposed instruments for search results analysis.

The results, mapped on the Figure 1, confirm the high researchers' interest to the topic of network capital. The growth rate of the number of publications about the network capital significantly exceeds the growth rate of all other publications placed together. Thus, the average growth rate of publications on network capital in the period from 1992 to 2016 amounted to $13.6 \%$, when the average growth rate for all subjects was only 5.3\%. This finding suggests that the topic of network capital gained great popularity and relevance with the development of information and communication technologies and rapid integration of modern communication technologies in the daily lives of people.

The information technology sector is one of the most dynamic, innovative sectors with the highest growth potential, due to the constant automation of global manufacturing processes and growing popularity of e-commerce. According to the Statistical Office of the European Communities (Eurostat) almost 3/4 (74\%) of all the European Union (EU) enterprises had their own web page or used the services of a third-part provider in 2014 (Eurostat 2015). Additionally, the "OECD Internet Economy Outlook 2015" data show that in the countries of the Organization for Economic Cooperation and Development (OECD), 95\% of businesses had broadband connection in 2015 up from 86\% in 2010 (OECD 2015). This phenomenon of rapid development and overall use of internet services is historically unique, especially taking into account that the Internet became available for the masses only in the late 1990s and the possibility to create an affordable and customized for their special needs webpage for commercial purposes appeared only in 2004 with the development of Web 2.0.

Social capital, with emphasis on the role of modern technology and new types of remote communication gradually extends to the socio-economic analysis focus. There is not much literature and studies available related to network capital; in this regard, this new type of capital has a great potential for research. At the same time, scientists involved in the research of the phenomenon of network capital, emphasize the problem of its measurement and definitions (M.Acevedo, B.Wellman, K. Frank, E.M.Uslaner etc.). Bari Wellman proposes to use frequency of social contact with friends, family and colleagues as an indicator of network capital (Wellman 2002, p.293), but Manuel Acevedo criticizes this approach, as these indicators are only a part of network capital and do not characterize it completely. Acevedo himself concludes that it is necessary to conduct a comprehensive study to develop a methodology for measuring network capital, which should be based on different interpretations of the concept of this phenomenon and factor analysis (Acevedo 2007, p.122). Basing on the theory of Michael Porter, one of the founders of the network capital theory, this type of capital should be considered much broader than only at the level of individuals - at the level of companies and even countries - agents, who generate this large-scale positive effect on the economy (Porter 1998, p.43-59).

Speaking of the lack of studies of this phenomenon in scientific literature, it is also important to note the inconsistency of terms. Often, scientists in their works write about social capital formed through electronic networks, without resorting to the term "network capital". Van Bavel, Punie and Tupomi writes about ICTenabled changes in social capital (Van Bavel, Punie, Tuomi 2004); Simpson analyses social capital through the interplay between physical infrastructure and soft technologies (Simpson 2005, p.102); Uslaner discusses social capital created in the Interenet (Uslaner 2004, p.61), to name a few authors and works. These works explore all the same phenomenon with the same characteristics that will be further considered in the paper under the definition of network capital. This difference in terminology can be partially explained by the interdisciplinary nature of the research of this type of capital, since it acts as the subject of attention of Sociology, Economics and Informatics.

In connection with these observations, the first part of the paper will be devoted to the definition of network capital, in turn, in the second part of the paper, the analysis of determinants of network capital formation and development will be made to refer to the current trends and to form a base for further research in this area. 


\section{The phenomenon of network capital and it's research methodology}

The analysis of scientific literature shows that researchers in their theories and concepts cannot get along without the concept of "network". First of all, economists and sociologists have integrated this concept when explaining the phenomenon of social capital. "Thereby social capital may be defined as benefit carrying resources that are associated with belonging to a group: the network of links that cannot be used otherwise than through the groups or people who have a certain power and who are able to provide a "favour for a favour"." (Mensikovs 2013, p.20). Even a more essential concept of "network" was proposed by John Urry in his monograph "Mobilities", who explains the emergence of sociology of mobilities through the role of different networks in modern society - through "network capital", which is actually an integral part of social capital. For Urry "network capital - is the ability to generate and maintain social relationships with people who are not necessarily located in the geographical neighbourhood, getting from this relationship emotional, financial or practical benefits (although often these benefits are enclosed in different objects and technologies or different means of media networking)" (Urry 2007, p.197). When Urry reveals the content of eight elements of network capital, readers can understand the role of different technological advances in its development and growth, and particularly the role of information and communication technologies.

All types of a person's aggregate capital can be seen as network of different energies that can quickly change its configuration and significance of its individual components. Realized life strategy is always the result of a hybrid energy, connection and conversion of various types of aggregate capital.

The terms "hybrid", "hybridization" are noticeably spreading around substantive fields of various scientific disciplines. With regard to the means of communication, the effect of hybridization has been clearly and vividly described by Marshall McLuhan: "Hybridization or a compound of these forces (communications) opens especially favourable opportunity to discover their structural components and properties... These communication tools, as extensions of ourselves, are beyond our control and depend on us in their interaction and evolution. The fact that they interact and multiply new offspring eternally has been a source of wonder" (McLuhan 1994). Of course, hybridization of various types of aggregate capital of a person was and still is a source of wonder, being "extension of ourselves", demonstrating an amazing set of different energies, qualities and characteristics that are in demand by our increasingly complex being.

In the late 20 th and early 21 st century, social field scientists were increasingly using the capital theory. The great contribution to the development of this theory has been made by Pierre Bourdieu (Bourdieu 1986). Basing on his theory and methodology, were discovered how to integrate different types of human capital into the concept of "aggregate capital" and how to use it more variously in empirical studies of different social problems. The greater use of this approach for the first time was proposed at the international conference in Nalęczow (Poland): "We have to try to empirically determine the role of aggregate capital of a person or group, correlation and significance of its individual forms" (Menshikov 2008, p.180-186).

In 2008, the Institute of Social Studies of Daugavpils University implemented the project "Paradigm of Education: A Sociological Approach", where an important place was given to the theory of aggregate capital - both in assessing the situation in the education system and the development of practices to improve the quality of education solutions (Menshikov 2011, p.149-160). During this project, the classification of different types of aggregate capital was developed, their incorporated, objectified and institutionalized state was described, and appropriate stratification systems, transmissions and measurements were presented. The aim of the research project was to overcome fragmentation of the theory of aggregate capital. To meet this goal an extensive classification of capital types was developed, were proposed indicators of its measurement. The following types of aggregate capital were studied empirically: economic, cultural, human (vocational and educational), physical, social, symbolic, geographical, administrative, political. (Menshikov 2016, p.89). In general, the empirical data confirmed the hypothesis: the amount of the individual capital depends on the level of education, level of income, as well as life strategy. 
In 2012, the Institute of Social Studies of Daugavpils University implemented the research project "The aggregate capital, its structure and relationship to labour migration", which has widely used the theory of aggregate capital (Menshikov, Vanags, Volkova 2013, p.226-236). During the study it was planned to evaluate the volume and the structure of aggregate capital of the inhabitants of Latgale, taking into account the needs of socio-economic development, as well as the expectations of people in the region, related to labour migration. Acceleration, dynamics, movement, moving, and other characteristics of the e-society became the basis of the emergence of sociology of mobility. The spread of new mobile network multiplies the capital, promotes network solidarity, expanding access to various activities and to the mobile lifestyle.

This requires increased attention of sociologists and other specialists in the fields of human and social sciences to mobility, to new features in modern lifestyle, especially lifestyle of the youth, who acquire the means of mobility faster than others. For this aim, in 2014 the Institute of Social Studies of Daugavpils University carried out a research project "Mobile lifestyle of modern youth" (Menshikov 2014, p.247-253). The findings of the sociological survey in Daugavpils $(n=355)$ suggest that in conditions of the e-society formation an access to the mobile lifestyle is expanding. The most important factors in favour of mobility are not only hardware and equipment (computers, mobile phones etc.), but the humanitarian and social technologies that allow to expand and enhance a network of solidarity, to accumulate network capital. The accomplished research projects have shown the importance of the aggregate capital theory, have brought important results in the analysis of various problems of the e-society formation. There is a growing role of non-economic types of aggregate capital in the implementation of people's life strategy. An important conclusion was made: the role of network capital and cultural capital is growing dramatically.

To understand the basic concepts of network capital, a wide range of literature and scientific articles has been analysed. Michael Porter has made a significant contribution to the establishment of the importance of network capital, showing that network structure is one of the main engines of modern economy. Porter has proved that success of companies crucially depends on a larger structural unit - the cluster, whose part it is. The cluster can be estimated as a network of suppliers, manufacturers, consumers, elements of industrial infrastructure, research institutes, interconnected in the process of creation of benefit. Thus, as the core of the cluster, as a rule, serves a large firm or a community of similar firms that through vertical (chain of purchases and sales), as well as horizontal links (additional products and services, the use of similar specialized processes, technologies or institutions) interact with other organizations participating in the cluster. In addition to the cluster core, a significant contribution to the interaction of a single cluster is made by organizations that provide the necessary infrastructure and communications, as well as technology and information. Through these intermediaries the creation and further successful operation of the cluster becomes possible, and thus the formation of a network capital is achieved.

Michael Porter writes that "companies can source capital, goods, information, and technology from around the world, often with the click of a mouse, much of the conventional wisdom about how companies and nations compete needs to be overhauled. In theory, more open global markets and faster transportation and communication should diminish the role of location in competition. After all, anything that can be efficiently sourced from a distance through global markets and corporate networks is available to any company and therefore is essentially nullified as a source of competitive advantage" (Porter 1998, p.43). Thus, the evolution of information and communication infrastructure is one of the most important and significant conditions for the network capital development. In his later works, Michael Porter gives special importance to the Internet as a means of communication between clusters.

Further, many scientists develop the idea of network capital (M.Acevedo, B.Wellman, L.Simpson, A.QuanHaase and B.Wellman, P.S.Adler and S.W.Kwon, J.Witte and K.Hampton, E.M.Uslaner, K.Frank, E.Sik etc.) and despite the fact that scientists use different terminology, the concept of network capital remains extremely necessary and topical. Manuel Acevedo researched network capital in the sphere of economic influence. In his work "Network Capital: an expression of social capital in the Network Society", he writes that in the economic context network capital is an important engine of economic development, by ensuring cooperation, which 
would not be impossible without it (Acevedo 2007, p.117). In the literature, two major areas of the positive effects of network capital are underlined: firstly, it is an important condition for human development and, secondly, it is an important condition for the exchange and redistribution of the world's resources and enhance of the world productivity.

In this case, very interesting is the article of Baiburina E.R. and Zhukavets O.S. Authors carried out the analysis of network capital as a driver of the company's value from the position of the management science. Taking into account that the category "value" is one of the central values in economics, resulted analysis is also valuable for representatives of economic theory. One can agree with the definitions of network capital on the micro level (on the level of one company), which formulate authors of the article: "network capital is a set of synergies, which company acquires from the network communications and corporate networking resource capabilities" (Baiburina E.R. Zhukovec O.S. 2009, p. 131). However, the characteristic of the network capital as one of the types of intellectual capital proposed by authors is fallacious. From the point of the theory of society, in compliance with the concept of sociologist Talcott Parsons "System of Modern Societies (Foundations of Modern Sociology)", intelligence and knowledge are related to culture as a social subsystem (sample reproduction and fiduciary subsystem), whose main function - sample reproduction in society. While social interactions are related to the other sub-system of society - societal community, whose main function is integration (Parsons T. 1971). The authors themselves noted that integration and resource mobilization - is a factor of the company's intellectual growth, rather than its component (intellectual capital and its components is one of the major sources of company`s organic growth, growth that takes place due to the integration of its internal resources). When authors go on to the analysis of strategic management in order to use network capital as a driver of company's value, they rather successfully form their own models of network capital growth, basing on publications in international journals. Unfortunately, authors do not distinguish real and virtual space, which becomes crucial for modern business partners`social interaction.

Another interesting network capital research at the micro level was carried out in 2016 by authors Claudia Smith, J. Brock Smith and Eleanor Shaw, considering network capital in terms of private enterprises (Smith C., Smith J.B, Shaw E. 2017, p. 18 -34). The authors examined how entrepreneurs accrue, build and employ social capital in the digital environment. As a result, research scientists have put forward 12 proposals on how the social networks formed in the virtual space influence the social capital of enterprises, as well as confirmed the conclusion that this type of capital is significantly different from the social capital on the basis of personal contacts, showing it in 10 action mechanisms. This observation confirms the need to distinguish network capital as a specific and unique type of social capital, which material base serves ICT infrastructure. Nevertheless, the literature analysis showed that many studies ignore this need.

In the article „The impact of virtual embeddedness on new venture survival: Overcoming the liabilities of newness" (Morse E.A., Fowler W.S., Lawrence T.B., 2007, p.139-159) the authors very deeply analysed the concept of virtual embeddedness of enterprises, which is actually a skill and the ability to accumulate network capital, and developed a theoretical model of the impact of virtual embeddedness on the development of new enterprises. However, the authors were unable to confirm the model with practical research and in the conclusions of the article they emphasize the need to carry out a quantitative analysis of data on a practical example.

Speaking of network capital within the enterprise as an economic entity, an interesting article about a business partnership, based on the network structure (Fuschi, Tvaronaviciene 2016, p.282-289) was published in 2016. The authors propose a new approach to managerial design of a company, based on a mutually beneficial network of partner relationships, to achieve high-quality and efficient management. This approach is based on more than 20 years of experience and the authors believe in the prospects of the model, so they expressed interest in the registration of a trademark, what indicates the innovativeness and relevance of network capital in the modern economy.

The paper „Benefits of social capital for sustainable innovation capabilities” emphasizes social capital as a driving factor for organizations while conducting innovations. (Laužikas, Dailydaitė 2013, p.85-97). The authors 
explore the added-value of social capital of companies and recognize the importance of networking between enterprises as an element of their development. Also of interest is the authors approach to the representation of a causal relationship between social capital and innovation, considering also reverse impact of social networks on innovation and confirming the positive reverse impact.

The Hungarian sociologist Endre Sik studies the role of networks in the cooperation of enterprises separated by geographical boundaries and distances (Sik 1994, 53-72). In his works he emphasizes two more factors that must be considered along with the network capital - informality and partial trust between cooperating agents of a network. Exactly this combination of complementary and, in fact, impossible without each other components is the main factor for the successful increase of social capital and the mechanism of economic development.

A significant contribution to the evolution of ideas and phenomenon of network capital has been made by the sociologist and co-director of the Toronto-based international NetLab Network Barry Wellman. Many of his studies have been conducted in collaboration with scientists from the computer field and computer science. In cooperation with Caroline Haythornthwaite, Barry Wellman examined the causes and the results of computer field scientists' partnership using online and offline environment. The researchers came to the conclusion that the creation of networks and friendship between scientists promotes the best results of their work. In cooperation with colleagues, Barry Wellman carried out studies about the efficiency of work processes' network organization in enterprises and researches about the relationship between citation of scientific articles and social ties of scientists (Haythornthwaite and Wellman 1998; Quan-Haase and Wellman 2007; White, Wellman, Nazer 2004). His later researches are focused on the analysis of the use of different types of communication, especially remote communication, and the study of their impact on various fields of activities. Barry Wellman showed how ICT development contributes to a society transformation from individual associations (groups) to networks, facilitating the mobility of goods and labour force and the globalization going beyond earlier limits.

In 2011 was published the study of Yoojung Kim, Dongyoung Sohn, Sejung and Marina Choi dedicated to cultural differences in the motivation for the use of social networking web pages (Y. Kim et al. 2011, p. 365-372). The authors used a survey of US and Korean college students to compare their experience of using online communities for the formation of social capital in the network. As a result, the study concluded that fundamental cultural values have significant influence on the ability to use network capital. These cultural values are very important in motivation of individuals to create bonds and contacts in the digital space. For example, Korean students are increasingly using the Internet community and specialized social networks for obtaining social support and to maintain the existing social relations, when American students give higher priority to entertainment and making new contacts, and therefore the network of US students is much wider and larger.

German sociologist Norbert Bolz writes about networks: „Network is a system of competition, where nodes are fighting for links; the more links node can attract, that is, the more links to the node is given, the more viable it is. For the economy, linking is important as the social added value: consumer choices are developing into links, which form the network. The most successful products of the 21 st century are no longer determined by the material value, but by their "linking value". In other words, the value of a product is expressed by the amount of links in which it became involved by buyers. Therefore, the goods' social added value is at the centre of a new marketing strategy and many speculate, that now it is better to say not "marketing", but "societing". Thus, the motto of the internet economy says: connection is more important than the thing, which it connects" (Bolz N. 2007, p 132-133). The aggregate capital theory states that any kind of aggregate capital in varying degrees can be converted to economic capital. Therefore, it can be said that the social added value converts into economic added value.

Considering the methods of network capital measurement, it is necessary to note that a single methodology has not been developed and implemented on a large-scale project yet. Determination of network capital on a global and regional level is a very difficult process. Regarding the specific methods used by scientists before, it has been concluded that these methods are very limited, aimed at studying individual network capital of some specific associations, interest groups or particular enterprises, and do not provide extensive knowledge 
and global conclusions. For example, the sociologist S.Cohen developed a technique that allows to calculate the Social Network Index (index of social network) based on the method of survey with the use of specially designed questionnaires (Cohen, S., Doyle, W., etc. 1997, p. 1940-1944), but again, the use of this method to a wider audience requires a lot of time and resources.

Thus, a very few studies have been conducted in the field of network capital and the authors of previously mentioned works have confirmed the necessity for further development of this vital topic. It is noteworthy that most of the works focus on the personal aspects of the relationship that prevents highlighting the importance of network capital for the concept of economic efficiency. Moreover, in the works, which use an empirical analysis, a network of certain groups and communities is discussed without departing from one organization, what also does not provide objective results for the representation on the global or regional level. The concept of networks is widely used at the level of one enterprise, scientists begin to realize the importance of this new and little studied form of capital and its influence on the development of enterprises. The concept of network capital gained more popularity in recent decades, but we still know relatively little about possibilities of quantification of network capital and determination of its impact on the economy. We need to understand how to develop social networks and use them for the benefit of national and regional economies. Therefore, an important step in the research in this area is an empirical analysis of network capital and the factors that shape it and determine its impact on the economy.

\section{Network capital analysis in the context of information and communication technologies development}

As stated earlier in the paper, network capital is a difficult to measure phenomenon, especially in the global and regional context. However, there is a number of factors and different indexes representing, firstly, base or infrastructure for the establishment and elaboration of network capital and, secondly, indicators illustrating the level of its development. In other words, despite the complexity of network capital measurement, it is necessary to conduct an analysis of the factors that impact and determine network capital. Additionally, in this part of the article the indexes indirectly or directly indicating the volume of network capital will be analysed.

Figure 2 shows the main indicators of global information and communication technologies in the period from 2005 to 2015, expressed in comparable units per 100 inhabitants. These values characterize the level of infrastructure development necessary for the formation of network capital, as well as the potential for further development of networks.

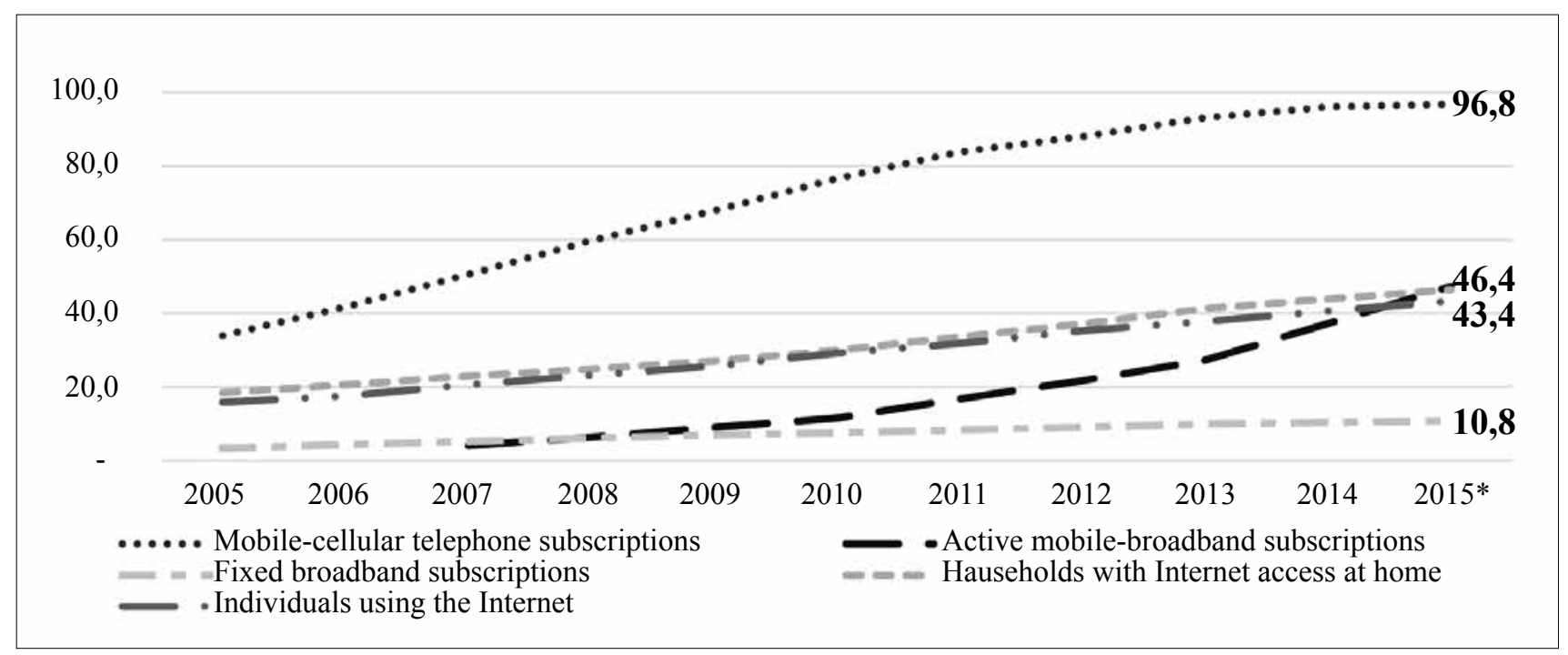

Fig. 2. Key ICT indicators for the world 2005-2015 (penetration rates her 100 inhabitants), ${ }^{*}$ estimate 
First of all, the sharp increase of the indicators in the observed period can be evaluated very positively. This indicates the development of digital infrastructure and thus improved conditions for the development of network capital. Especially rapid is the increase in the number of mobile phone users, which is caused by the transition from a fixed wire phone communication to a new method of wireless connection. The same replacement trend is obvious for the indicators "fixed broadband subscriptions" and "active mobile-broadband subscriptions".

Over the ten-year period, compared with 2005, the number of mobile-cellular telephone subscriptions increased 2.9 times (the average growth rate of $11.3 \%$ ), the number of fixed broadband subscriptions grew 3.2 times (the average growth rate of $12.6 \%$ ), the number of households with Internet access at home went up by 2.5 times (the average growth rate of 9.7\%), the number of individuals using the Internet grew 2.7 times (the average growth rate of 10.7\%) and between 2007 and 2015 the number of active mobile-broadband subscriptions went up by 11.7 times (the average growth rate $36.4 \%$ ). This rapid growth is based on advances in technology, fall of their prices and increasing dependence on ICT services. The data of "Measuring the Information Society Report 2015" show that the prices of mobile-cellular in 2014 fell by $12 \%$ and mobile-broadband - by $25 \%$ compared with 2012 (International Telecommunication Union 2015, p.11). In developed countries, IT services are equally used almost in all sectors of economy, modernizing and automating goods production and transferring trade and services to the online environment. Returning to the example of Estonia, it is worth mentioning such important kinds of online networking as e-government, i-voting, e-tax board, e-business, e-school etc. Of course, attention should be paid also to contemporary social transformation - the change of usual methods of communication and the creation of social ties in the digital environment.

Another important observation is a slowdown of certain indicators. If the number of mobile-cellular telephone subscriptions slows its growth in connection with the approach to the peak, then falling growth rates of the number of households with Internet access at home and the number of individuals using the Internet, may be a signal of the market surfeit and may point at the need to solve the problems that hinder the further growth of indicators. Taking into account that both indicators are the most significant in the context of network capital, since they characterize access to ICT and use of the world's digital space, where these networks are formed, an improvement of the situation of uneven world region development on a regional level is a very important task.

The data show that more than a half the world's population in 2015 had access to broadband (47,2 out of 100 people - mobile telephony, 10,8 - fixed), 46,4 out of 100 households had access to the Internet and 43,4 out of 100 people used the Internet. On the one hand, given the importance of information technology in modern world, these figures are quite low: in fact, less than half of the world's population in their daily operations use the opportunities of the digital space. On the other hand, not all countries have achieved a certain level of development at which it becomes impossible to do without innovative technologies and the level of income at which a country's population can afford these technologies in everyday life.

The Figure 3 displays the above-analysed indicators considered for the two groups of countries: developed and developing countries (the classification based on UN M49). The data show that the level of ICT infrastructure in developed countries is far ahead of the level of developing countries. This digital divide is explained, first of all, by a lower standard of living, due to which people in developing countries cannot afford to use innovative means of communication. This fact directly points at a poorly developed network capital and insufficiently used possibilities of network capital in these countries. Speaking about the potential of network capital in less developed countries, the amazing pace of ICT development should be noted. Between 2005 and 2015, the average growth rates in developing countries exceeded the growth rates in developed countries at an average of three times. Yet again, it is worth paying attention to the trend noticed earlier: the reduction of growth rates over time. This trend is typical for both developed and developing countries (International Telecommunication Union 2015). If in the developed countries this observation is attributable to the approximation to the surfeit point, in the developing countries this indicates fairly low limits of technology development, and thus limits of the network capital capacity if the situation does not change. 


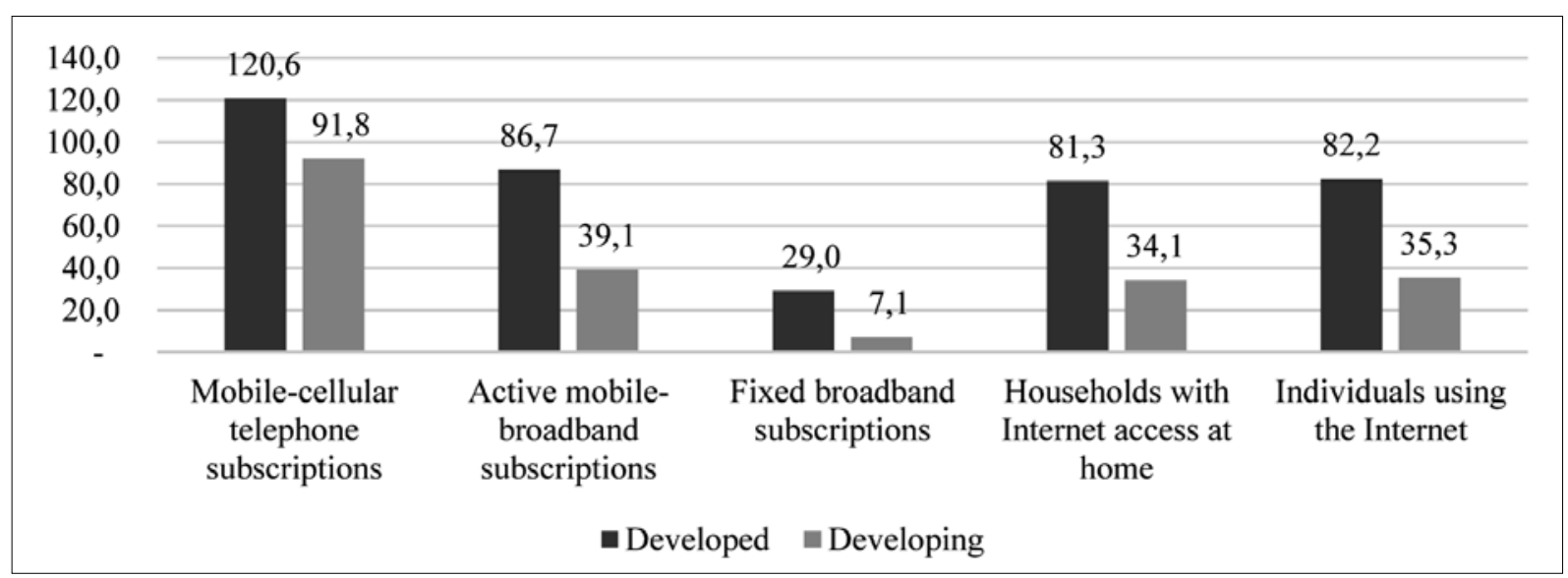

Fig. 3. Key ICT indicators in developed and developing countries $2015^{*}$ (penetration rates her 100 inhabitants)

Source: ITU Plenipotentiary Conference 2014 (PP-14), available: http://www.itu.int/en/plenipotentiary/2014/Pages/default.aspx

Returning to the value of the indicators, it should be noted that $82.2 \%$ of the population in the developed countries used the Internet in 2015, which is an extremely high rate, making a discount on population, dropping out from the category of Internet users (mostly by age). However, the rate was only $35.5 \%$ in the developing countries, indicating a low availability of networks and thereby the little possibilities of network capital use. Regarding the differences in the availability of ICT "Measuring the Information Society Report 2015" states that in many developing countries, for example, there are substantial differences in telephone and Internet penetration between urban and rural areas, often exacerbated by the lack of broadband capacity in the latter. A significant digital divide persists between men and women in many countries, and there are widespread digital divides between those with more or less income, associated with ICT affordability; with higher or lower educational attainment, particularly associated with the capabilities required for Internet use; and with other factors affecting the inclusion or marginalization of particular social groups, for example, persons with disabilities (International Telecommunication Union 2015, p.3). To reduce this social inequality in terms of ICT development and to improve global access to ICTs (including decrease in prices) the strategy "The Connect 2020 Agenda" has been developed, which can significantly affect further positive changes in the development of network capital.

Next, the level of ICT infrastructure development across regions will be considered. The data is summarized in the Figure 4.

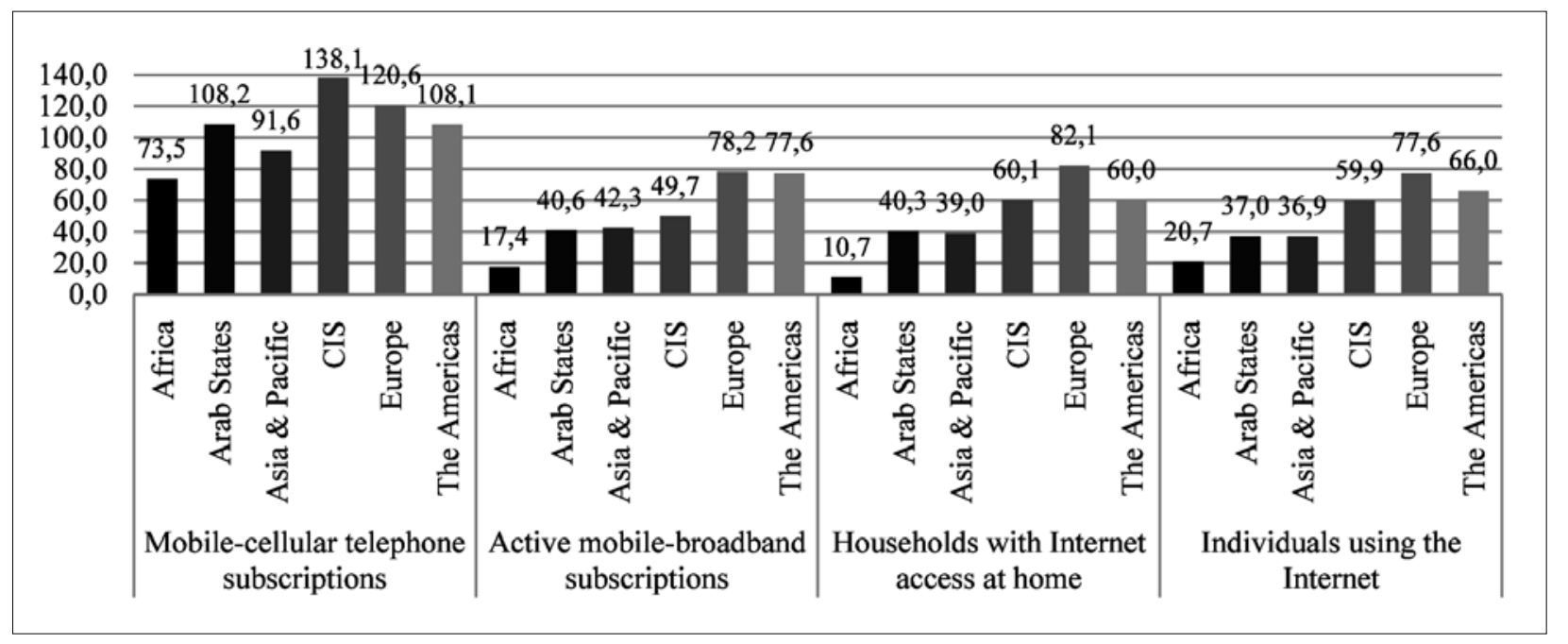

Fig. 4. Key ICT indicators by region $2015 *$ (penetration rates her 100 inhabitants) 
Statistics show that the leader in terms of network capital infrastructure is Europe presenting $82.1 \%$ of households with Internet access at home and $77.6 \%$ of the population using the Internet. The second place belongs to America and here it should be noted that in terms of the ICT development and their accessibility, North America can compete with Europe for leadership, however, in the available statistics North America's data is combined with South America's indicators, what distorts the results. The last place takes Africa, due to a wide gap from other regions in terms of all indicators, what is directly linked to economic factors. All these observations lead to the conclusion that in the developed countries with a higher level of well-being, network capital can be explored faster and on a larger scale than in the less developed regions.

One of the main reasons for this variance in the level of ICT development and use is the difference in prices. Figure 5 shows the data for mobile-broadband prices in the countries, divided into groups depending on the level of its development: developed, developing and least developed countries. The data in the graph is expressed as percentages of gross national income per capita, which allows to evaluate the real situation very well not in absolute figures, but rather in terms of purchasing power. The graph shows how big the difference between prices in different countries is depending on their level of a contry`s economic well-being. We can see that technologies in the developed countries are many times more affordable than in lower-income countries. For example, prices for prepaid computer-based communication, expressed on a comparable basis, in developed countries are 7 times lower than in developing countries and 15 times lower than in the least developed countries. This fact can be evaluated very negatively, since it indicates a major problem hindering the development of the network capital in the less developed countries of the world.

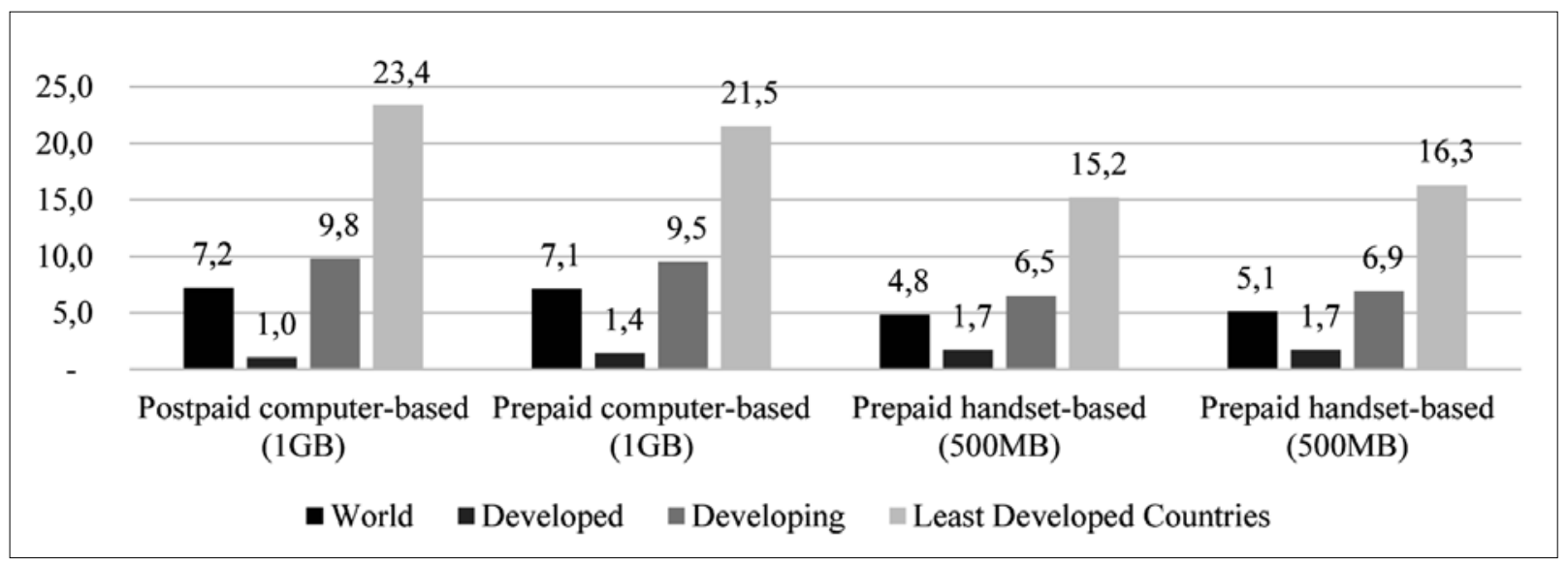

Fig. 5. Mobile-broadband prices, developed and developing countries and LDCs, 2014 (\%gross national income per capita)

Source: Measuring the Information Society Report2015, available: http://www.itu.int/en/ITU-D/Statistics/Documents/publications/misr2015/MISR2015-w5.pdf

Besides the problem of high price differentiation, there is also a significant problem with access to digital technology - the uneven coverage of broadband. At "ITU Plenipotentiary Conference 2014", presented data has shown that if in the developed countries mobile coverage reaches almost $90 \%$ of territory, then in the least developed countries it is just above $10 \%$, what significantly affects both the quality and the availability of the network. This factor is mainly connected to the low financial impact of network infrastructure investments due to the low income level of population. That makes it important to consider the possibility of public investments in network infrastructure to improve the availability of ICT, as well to consider the opportunity to develop more affordable network products with lower efficiency and at lower price. Continuing the idea of network coverage, problems with ICT infrastructure in rural areas should also be noted. Materials of "ITU Plenipotentiary Conference 2014" show that $89 \%$ of the world urban areas have 3 G coverage when the coverage rate for rural areas is only $29 \%$. These observations lead to the conclusion about uneven technological development of world regions: urban population and population of the developed countries initially have much greater opportunities for the use of network capital than the population of rural areas and countries with a lower level of development. 
Another noteworthy indicator of network capital is the ICT Development Index (IDI), an index published by the United Nations International Telecommunication Union, based on internationally agreed information and communication technologies (ICT) indicators, summarizing the 11 indicators and which is the main indicator to measure the formation and development of information society. It can be used to monitor and compare developments in information and communication technology between countries and over time (International Telecommunication Union 2015, p.39). The index is based on three main characteristic areas: availability of ICT, use of ICT and ICT skills, thereby determining the overall impact of ICT on society. All these indicators very well fit into the theory of network capital, reflecting the infrastructure for its development and use of network communications for its formation, in other words, the potential of its accumulation. This term has not been used previously in the literature; however, it very aptly describes the idea of the index. The first five places in the IDI in 2015 occupied South Korea, Denmark, Iceland, United Kingdom and Sweden. Latvia took 37th place, by 17 points behind from Estonia (20th place), 3 points ahead of Lithuania (40th place) and gaining 7.16 points at 8.93 points in leading South Korea (International Telecommunication Union 2015).

The next step of analysis was to identify relation between network capital and economic development. ICT Development Index has been chosen as an indicator of the network capital capacity, and GDP per capita in Purchasing Power Parity (PPS) - as the indicator of economic development. The results are reflected in the Figure 6.

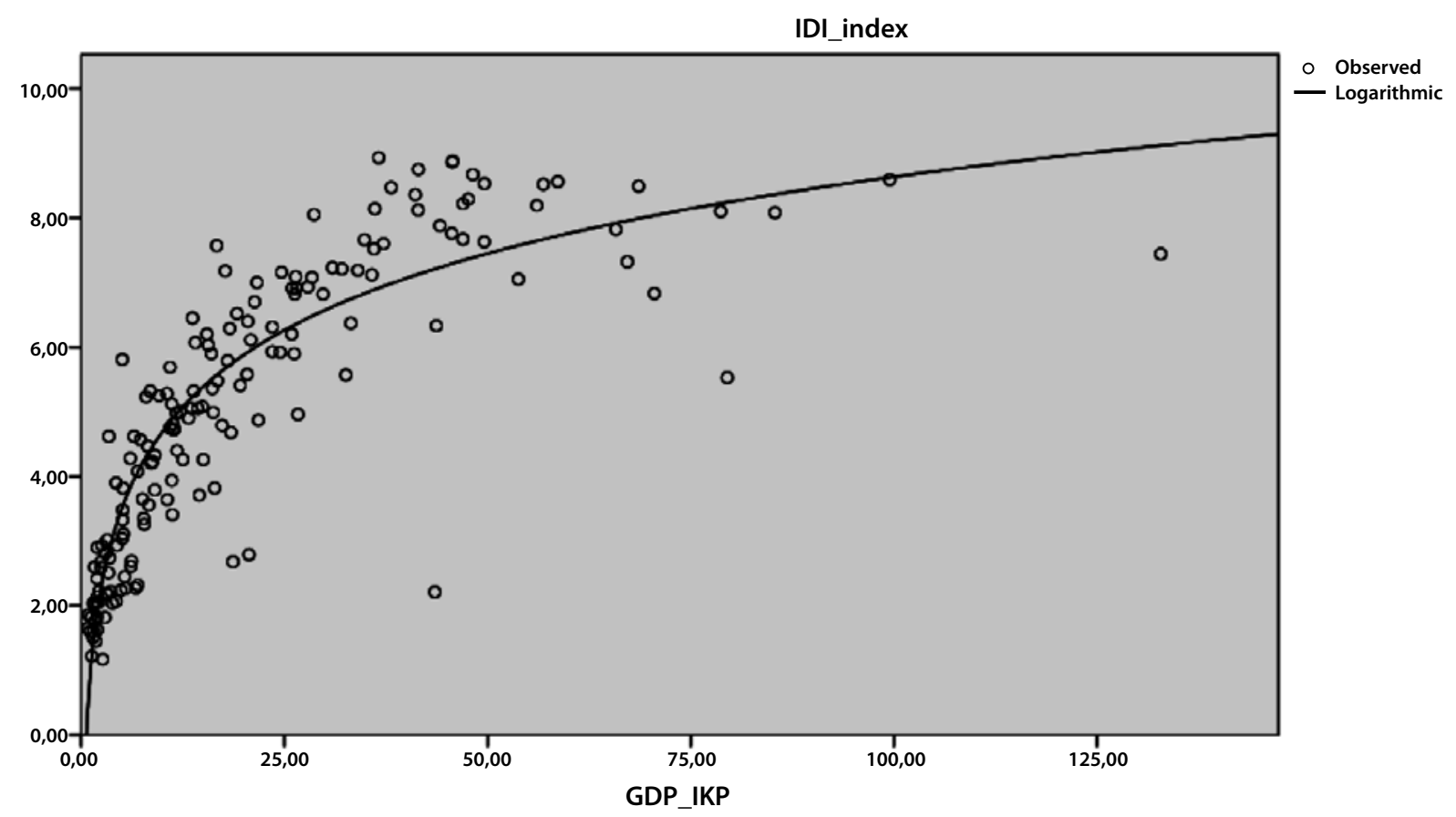

Fig. 6. ICT Development Index (IDI) and Gross domestic product (GDP) per capita relation, 2015 (n=166)

Source: Authors`calculations, based on the data about GDP per capita 2015 from International Monetary Fund and IDI data from Measuring the Information Society Report2015

The analysis showed that there is a very strong positive relationship between the potential of network capital accumulation and economic development: the higher the potential of network capital accumulation is, the higher is the level of the country's development (correlation coefficient 0,890 ; p-value 0,000 ). However, this relationship is not linear, but logarithmic: with the increase in coefficients, the positive effect decreases. That means reaching a certain high point, when, with the increase in GDP per capita, the potential of network capital accumulation does not growth. This dependency may be expressed as a regression equation: IDI $=0,751+1,712 \mathrm{ln}$ (GDP per capita). A strong relationship can be explained by the financial possibilities of the higher-income countries, thus, high investments in ICT infrastructure and the dependence of the economy of the ICT in more developed countries. Similar results showed the analysis of the IDI subindexes (ICT access, ICT use and ICT skills), which revealed a strong subindexes relation with GDP per capita. 
Among individual countries, particularly interesting cases are those breaking out from the general trend. Positive examples are Estonia (throughout the whole research showing remarkable results), South Korea, Moldova, Belarus and Barbados, which show a significantly higher potential of network capital accumulation than expected at their level of GDP per capita. These examples are of particular interest and require further study. It is necessary to examine the policy of the ICT development in these countries to identify the factors contributing to such a positive outcome. An interesting observation is that Latvia also shows the result of above average with IDI 7.16 and GDP per capita 24.65.

Negative examples of inefficient use of the potential of network capital accumulation are primarily African (including Equatorial Guinea, Gabon) and Arab countries (including Kuwait, United Arab Emirates, Qatar, Brunei and Saudi Arabia). This fact is interesting, because the main Arab states' revenues are associated with the mining industry, pointing at the low significance of ICT in the economies of these countries. It can be concluded that the development of network capital is highly dependent on the industry structure in the country that makes it more or less interested in ICT investment.

The graph 7 shows the division of countries into 4 groups depending on the level of GDP per capita and ICT Development Index indicators.

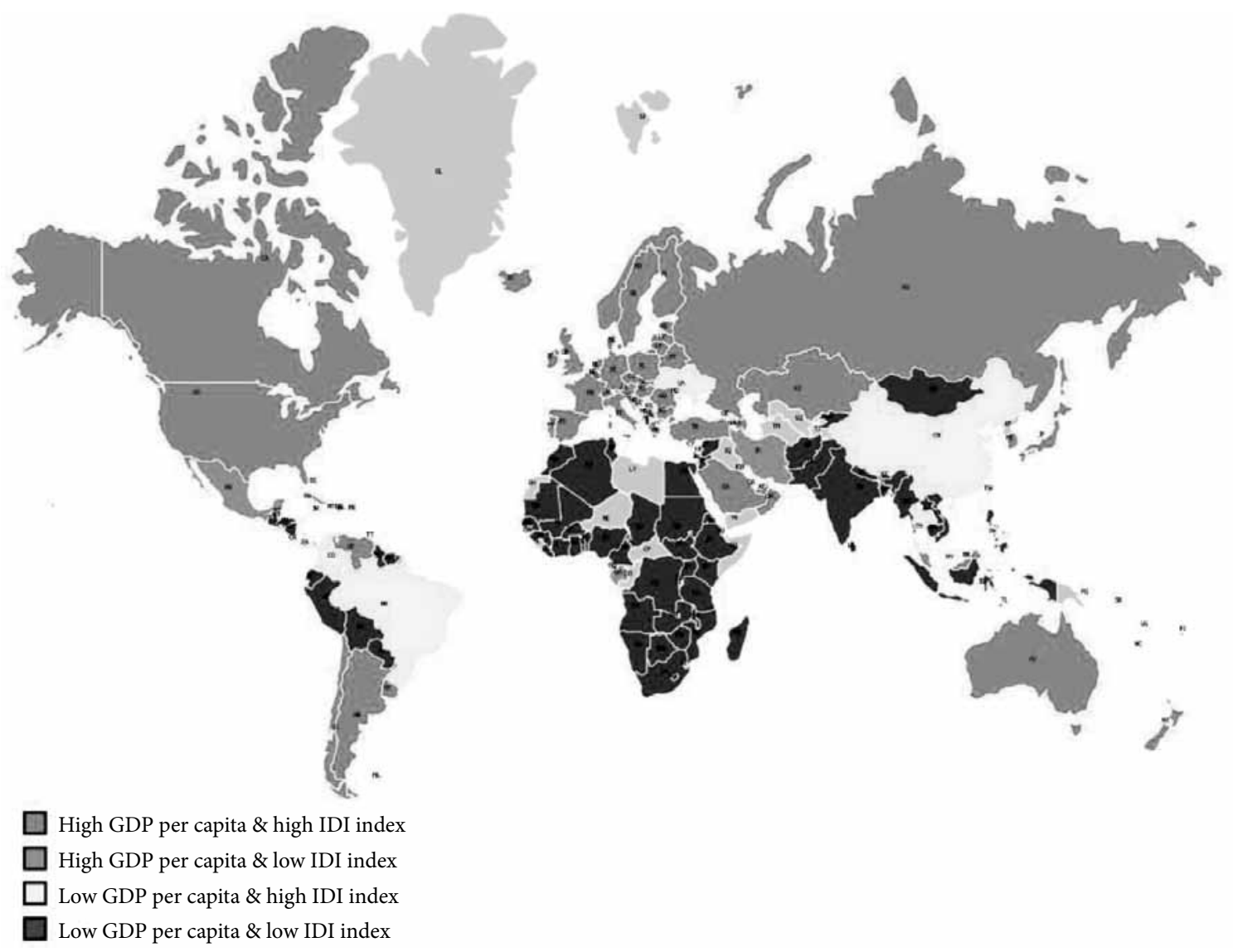

Fig.7. World countries division by level of ICT Development Index (IDI) and Gross domestic product (GDP) per capita, $2015(\mathrm{n}=166)$

Source: Made by authors, based on the data about GDP per capita 2015 from International Monetary Fund and IDI data from Measuring the Information Society Report2015

To determine the plase of each country in a particular group, the average level of IDI in 2015 (5.01) and the minimal level of GDP per capita (PPS) for high-income countries in 2015 according to the World Bank classification was used. Thus, all the world's countries have been divided into 4 categories: countries with low GDP per capita and IDI (red); countries with low GDP per capita, but high level of IDI (yellow); countries with high 
GDP per capita, but low level of IDI (blue) and countries with high GDP per capita and IDI (green). Grey color marks countries whose data were not available for analysis.

Graphical display of grouping lets see clearly expressed regional consistency of the results. Thus, high GDP per capita and ICT Development Index indicators are observed in the region of North America, Europe and northern Asia, as well as in the southern part of Latin America and Australia. Low GDP per capita and IDI indicators are typical for the African region, north-west of South America, southern parts of Asia and the northern countries of Australia and Oceania region. Countries that fall into these two categories are evidence of the earlier established relation between the development of information and communication technologies and the level of economic development of a region.

Of greater interest for the study are countries, which trapped in the category "high GDP per capita and low IDI index" and "low GDP per capita and high IDI index", as they are results out of the general trend. For example, the group of low-income, but high levels of ICT infrastructure includes such countries as Moldova, Ukraine, Bosnia and Herzegovina, and Serbia, whose policy of recent years has been focused on facilitating the introduction and development of ICT and support of IT and ICT companies. These countries use their advantage in the form of relatively low and thus competitive wages in the European region for the formation of new enterprises and attraction of foreign investment and customers. It can also be assumed that these countries are at the stage of investment in innovative technologies, when the return on the cost may not be felt in full, in other words, lag of ICT investment. It is quite possible, that they are in the time interval, which is required for enterprises to implement new information technology and learn to use them effectively. This period of time is highly variable and depends on the state of the IT market at the time of investment. A large positive impact of information technologies on the growth of GDP per capita is observed only after reaching a certain minimum threshold of IT development. In the case of China's presence in the group of countries with low income, but high level of ICT infrastructure, it is connected with the unique economic structure of the country. China is one of the few countries, which manages so effectively use low-skilled labour and physical labour of population, achieving good economic performance of high-volume production, without the need for large investments in ICT infrastructure.

In the category of countries with high income but low ICT levels is included Iran, whose stage of economic development is in the gradual transformation from a centrally-planned economy to a free market economy that has already affected the economic performance, but apparently the transformation has lesser affected ICT. In addition, the explanation to this could be the economic structure of the country, which is based on the sectors of mining and processing oil and natural gas. In the category of low IDI and high GDP are also included such countries as Gabon and Equatorial Guinea, whose place in the group can also be explained by the industrial structure, where an important place is given to the low-skilled manufacturing industry workforce, as well as agriculture. In Cuba and Mexico the highest employment is observed in tourism industry and size of the business in the countries is characterized by low-innovative small and medium-sized enterprises. That means that use of information technology and ICT infrastructure, and thus, the potential development of network capital in these countries is much lower. This group of high-income countries with the low level of ICT development is the smallest - it includes only 7 countries that confirms previously noticed relationship between the level of ICT infrastructure and the overall economic development of a country.

Another index that certainly deserves attention in the context of network capital is the Networked Society City Index (NSCI) by Ericsson in collaboration with Sweco, a leading consultancy firm specializing in sustainable development. The index seeks to inspire and contribute to society development around the world, and in cities in particular. It includes $40+$ major world cities and provides a framework for measuring ICT maturity in relation to social, economic and environmental progress. It can be used to exploit emerging possibilities associated with a connected world. Innovative ways to communicate and share information create new collaborations and organizations that are adapted to a more connected and individualized society (Ericsson 2016). In fact, this index is the only available indicator of network capital on a global scale; however, again, it includes only a small fraction of the world's cities (41 cities). It is worth noting that the developers of the index do not refer to the theory of network capital and do not use this definition. 
The results of cities' ranking in the Networked Society City Index are displayed in Figure 8. The Figure shows the relationship between maturity of ICT in the cities and triple bottom line measurements (TBL) - social, economic and environmental - reflecting the three dimensions of sustainable development of the cities. The result and place of each country in the index is based on this relationship. Thus, in the result, not only the level of ICT development in the city is important, but also the successful use of the opportunities that these technologies offer, what makes this figure very objective in terms of the characteristics of network capital.

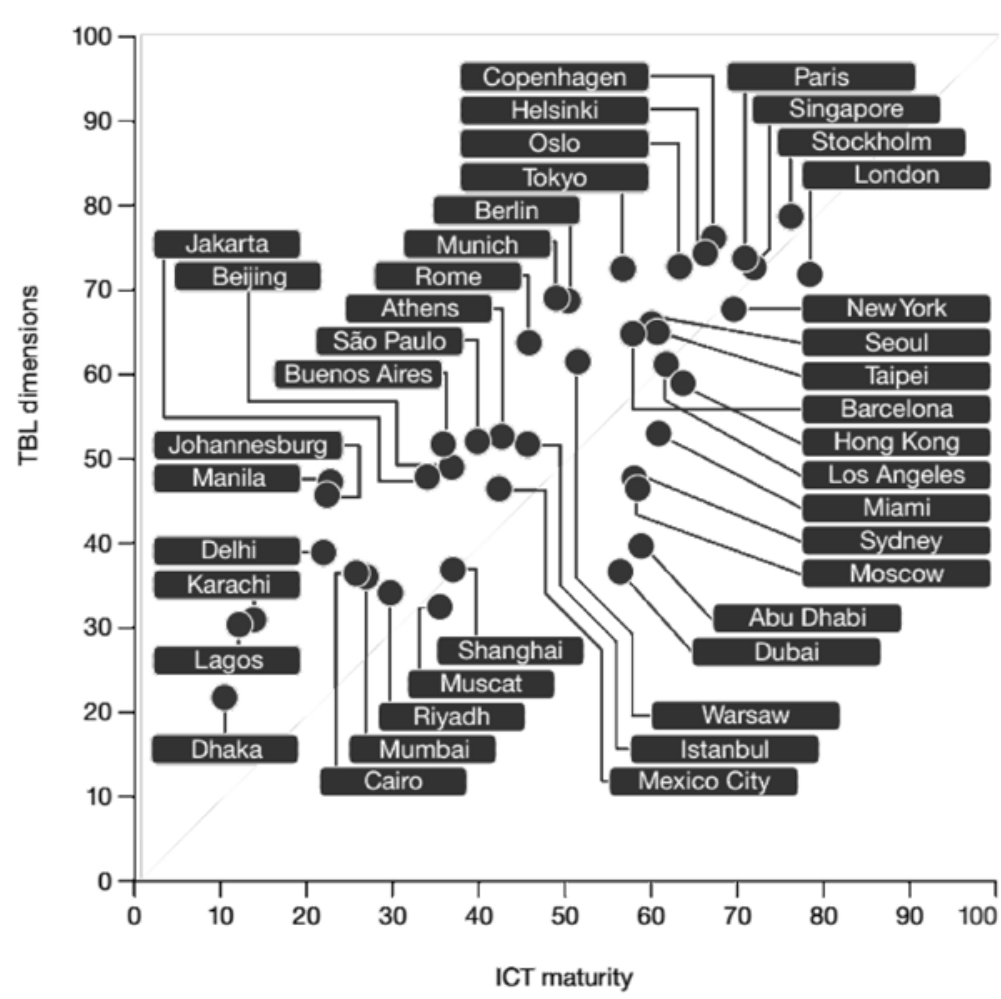

\begin{tabular}{|c|l|c|l|}
\hline Rank & \multicolumn{1}{|c|}{ City } & Rank & \multicolumn{1}{c|}{ City } \\
\hline 1 & Stockholm & 21 & Moscow \\
\hline 2 & London & 22 & Istanbul \\
\hline 3 & Singapore & 23 & Abu Dhabi \\
\hline 4 & Paris & 24 & Athens \\
\hline 5 & Copenhagen & 25 & São Paulo \\
\hline 6 & Helsinki & 26 & Dubai \\
\hline 7 & New York & 27 & Mexico City \\
\hline 8 & Oslo & 28 & Buenos Aires \\
\hline 9 & Tokyo & 29 & Beijing \\
\hline 10 & Seoul & 30 & Jakarta \\
\hline 11 & Taipei & 31 & Shanghai \\
\hline 12 & Los Angeles & 32 & Riyadh \\
\hline 13 & Barcelona & 33 & Muscat \\
\hline 14 & Hong Kong & 34 & Manila \\
\hline 15 & Berlin & 35 & Johannesburg \\
\hline 16 & Munich & 36 & Mumbai \\
\hline 17 & Miami & 37 & Cairo \\
\hline 18 & Warsaw & 38 & Delhi \\
\hline 19 & Rome & 39 & Karachi \\
\hline 20 & Sydney & 40 & Lagos \\
\hline & & 41 & Dhaka \\
\hline & & \\
\hline
\end{tabular}

Fig. 8. Networked Society City Index ranking and the relation between triple bottom line (TBL) and ICT maturity, $2016(\mathrm{n}=41)$

Source: Ericsson (2016). Networked Society City Index 2016 Edition

The data show that the leaders among the cities, analysed in terms of infrastructure and the accumulation of network capital, are Stockholm, London, Singapore, Paris and Copenhagen. This means that there are one of the highest levels of ICT development in these cities and at the same time the cities have got high marks in the triple bottom line dimensions. The correlation, identified in the index, indicates a positive relationship between the ICT development level and social, economic and environmental development. "Networked Society City Index 2016 Edition" explains this positive relationship as affluent cities have reaped the benefits of early industrialization and are indeed able to invest more in ICT and are, partly due to preconditions, better at utilizing ICT investments than developing economies (Ericsson 2016). An annual improvement, revealed by the index, is also worth mentioning, as it indicates the increasing importance of network capital and increase of the capital itself.

The empirical analysis of available statistics allowed to identify the main trends in the development of network capital at global and regional levels and revealed the strong dependence between the ICT infrastructure and the economic development of a country. By means of detailed analysis, it has been possible to identify the problems associated with the development of network capital and to provide a basis for further research on this topic. 


\section{Conclusions}

The analysis of literature and previously conducted studies has shown that the role and the capacity of network capital development is poorly understood, there are only few studies on this topic and they are not based on substantial empirical analysis. In theoretical studies, the differences in terminology and the interpretation of the phenomenon of network capital are observed. To determine the object of the study, the authors have formed the concept of network capital as a branch of social capital, which is based on the bonds formed by the use of ICTs.

It was stated that a large part of the previously conducted researches focuses on aspects of personal relationships and does not give a possibility to detail network capital for the concept of economic performance. Moreover, in the works, where an empirical analysis has been undertaken, networks of certain groups, communities and particular enterprises are discussed without departing from one organization, what does not provide objective results for the representation on the global and regional level. The concept of networking is widely used at the micro level, scientists begin to realize the importance of this little studied form of capital and its influence on the development of enterprises in the region. This finding gave rise to a further empirical analysis and has shown the need to find the capabilities of network capital measurement at the global and regional level.

The analysis of the main ICT infrastructure indicators` dynamics has shown positive trends in the development of conditions for the network capital accumulation. All observed indicators have shown a sharp increase in the period from 2005 to 2015 . However, some trends can be evaluated negatively: a slowdown of the growth rates of the number of households with Internet access at home and the number of individuals using the Internet. This conclusion leads to questioning the market saturation in the developed regions and the need to solve problems that hinder further growth rates in the less developed regions.

By means of the statistical analysis, it has been determined that the level of ICT infrastructure in the developed countries is far ahead of the level of the developing countries. This conclusion was confirmed by the analysis of the ICT infrastructure by region and the analysis of network capital by cities - network capital in developed areas with a higher level of well-being explores faster and on a larger scale than in the less developed regions. It has been concluded, that the development of network capital is highly dependent on the industry structure in the country that makes it more or less interested in ICT investment and support of the sector. The further analysis helped to establish that one of the main reasons for this variance in the level of ICT development and use is the difference in prices. In addition to a large differentiation in prices, there is a problem with the access to digital technology - the uneven coverage of broadband in developed and developing countries, urban and rural areas. That makes it important to consider the possibility of public investments in network infrastructure in less developed regions and rural areas to improve the availability of ICT, as well as to consider the opportunities to develop more affordable network products with lower efficiency and lower prices.

The analysis has shown that there is a very strong positive relationship between the potential of network capital accumulation and economic development: the higher the potential of network capital accumulation, the higher is the level of the country's development. However, this relationship is not linear, but logarithmic: with the increase in coefficients the positive effect decreases, which designates reaching a certain high point. The further analysis has shown that Estonia (showing remarkable results throughout the whole study), South Korea, Moldova, Belarus and Barbados demonstrate a significantly higher potential for network capital accumulation than expected at their level of GDP per capita. These examples are of particular interest and require further study.

Graphical analysis of the world countries grouping depending on the level of ICT infrastructure development and the level of GDP showed expressed regional consistency of the grouping results. Thus, high GDP per capita and ICT Development Index indicators are observed in the region of North America, Europe, and northern Asia, as well as in the southern part of Latin America and Australia. Low GDP per capita and IDI indicators are typical for the African region, north-west of South America, southern parts of Asia and the northern countries of Australia and Oceania region. 


\section{References}

Acevedo, M. 2007. Network Capital: an expression of social capital in the Network Society. The Journal of Community Informatics 3(2): 117-124.

Adler, P.S., Kwon, S.W. 2002. Social Capital: Prospects For A New Concept. University of Southern California. The Academy of Management Review 27(1): 17-40.

Allabouche, K.; Diouri, O.; Gaga, A.; El Amrani El Idrissi, N. 2016. Mobile phones' social impacts on sustainable human development: case studies, Morocco and Italy, Entrepreneurship and Sustainability Issues 4(1): 64-73. http://dx.doi.org/10.9770/jesi.2016.4.1(6)

Baiburina E.R., Zhukovec O.S. 2009. Koncepcija analiza setevogo kapitala kak draivera stoimosti kompanii. Journal of Corporate Finance Research. T. 3. No. 4: 130-144 (In Russian).

Bolz N. 2007. Das ABC der Medien. Fink, Wilhelm; Auflage: 1 (1. Juli 2007).

Bourdieu, P. 1986. The forms of capital. In J. Richardson (Ed.) Handbook of Theory and Research for the Sociology of Education. New York, Greenwood: 241-258.

Cohen, S., Doyle, W. J., Skoner, D. P., Rabin, B. S., and Gwaltney, J. M., Jr. 1997. Social ties and susceptibility to the common cold. Journal of the American Medical Association 277: 1940-1944.

Dlugoborskytė, V.; Norvilaitė, V.; Petraitė, M. 2015. Creativity and innovation management: team performance peculiarities, Entrepreneurship and Sustainability Issues 3(1): 25-39. http://dx.doi.org/10.9770/jesi.2015.3.1(2)T

Ericsson. 2016. Networked Society City Index 2016 Edition. Networked Society Lab: Stockholm. Available on the Internet: https://www. ericsson.com/res/docs/2016/2016-networked-society-city-index.pdf

European Commission; Eurostat. 2015. Digital economy and society statistics - enterprises. Available on the Internet: http://ec.europa. eu/eurostat/statistics-explained/index.php/Information_society_statistics___enterprises

Fuschi, D. L.: Tvaronavičienè, M. 2016. A network based business partnership model for SMEs management, Entrepreneurship and Sustainability Issues 3(3): 282-289. DOI: http://dx.doi.org/10.9770/jesi.2016.3.3(5).

Government Office of Estonia. 2016. E-Estonia. The Digital Society. What is e-Residency? Available on the Internet: https://e-estonia. com/e-residents/about/

Grubicka, J.; Matuska, E. 2015. Sustainable entrepreneurship in conditions of UN (Safety) and technological convergence, Entrepreneurship and Sustainability Issues 2(4): 188-197. http://dx.doi.org/10.9770/jesi.2015.2.4(2)

Haythornthwaite, H., Wellman, B. 1998. Work, Friendship and Media Use for Information Exchange in a Networked Organization. Journal of the American Society for Information Science 49 (12): 1101-1114.

International Monetary Fund. 2016. World Economic Outlook Database, October 2016. Available on the Internet: http://www.imf.org/ external/ data.html

International Telecommunication Union. 2015. Country classifications by region. Available on the Internet: http://www.itu.int/ITU-D/ ict/definitions/regions/index.html

International Telecommunication Union. 2015. ITU Plenipotentiary Conference 2014 (PP-14). ITU key 2005-2015 ICT data. Available on the Internet: http://www.itu.int/en/ plenipotentiary/2014/Pages/default.aspx

International Telecommunication Union. 2015. Measuring the Information Society Report. International Telecommunication Union: Geneva. Available on the Internet: http://www.itu.int/en/ITU-D/Statistics/Documents/publications/misr2015/MISR2015-w5.pdf

Kim Y., Sohn b D., Choi S.M. 2011. Cultural difference in motivations for using social network sites: A comparative study of American and Korean college students. Computers in Human Behavior 27: 365-372.

Laužikas, M.; Dailydaite, S. 2013. Benefits of social capital for sustainable innovation capabilities, Journal of Security and Sustainability Issues 2(3): 85-97. http://dx.doi.org/10.9770/jssi.2013.2.3(7)

Menshikov, V. 2008. Capital in Sociological Aspect: Theoretical Bases of Investigation and Operational Parameters. Kultura a Rynek. Lublin: Wydawnictwo KUL: 180-186.

Menshikov, V. 2011. Human capital in the structure of total capital of a personality: sociological aspect. Philosophy.Sociology.t.22, Nr.2. 
Vilnius, Lithuanian Academy of Science: 149-160.

Menshikov, V. 2013. Kopkapitals, ta struktura un saikne ar darba migraciju (uz Latgales piemera). The materials of the International Scientific Conference "Social Sciences for Regional Development 2012: Impact of the financial capital on the region's economic competitiveness", Part 1. Issues of Sociology. Daugavpils University, Saule: 19-40.

Menshikov, V. 2014. Mobility in the lifestyle of today's youth. Philosophy. Sociology 25(4) Vilnius, Lithuanian Academy of Science: 247-253.

Menshikov, V. 2016. Experience of research of social classes in Latvia. Philosophy.Sociology 27(2). Vilnius, Lithuanian Academy of Science: 83-92.

Menshikov, V., Vanags, E.,Volkova, O. 2013. Sociological interpretations of data on the aggregate capital of regional population (work experience abroad, relation to labor migration, factors of life success). Philosophy. Sociology 24 (4). Vilnius, Lithuanian Academy of Science: 226-236.

Morse E.A., Fowler W.S., Lawrence T.B. 2007. The Impact of Virtual Embeddedness on New Venture Survival: Overcoming the Liabilities of Newness. Entrepreneurship: Theory and Practice. Volume 31, Issue 2, March 2007: 139-159.

Organisation for Economic Co-operation and Development (OECD). 2015. OECD Digital Economy Outlook 2015. OECD Publishing, Paris. Available on the Internet: <http:/www.itu.int/en/ITU-D/Statistics/Documents/publications/misr2015/MISR2015-w5.pdf >.

Parsons, T. 1971. System of Modern Societies (Foundations of Modern Sociology). Prentice Hall (September 24, 1971).

Pinto A.L., Gonzales-Aguilar A. 2014. Visibility of studies in social network analysis in South America: Its evolution and metrics from 1990 to 2013. Transinformacao. Volume 26, Issue 3, 1 September 2014: 253-267.

Porter, E.M. 1998. Clusters and the New Competiotion. Harvard Business Review. November-december ISSU E: 43-59.

Prause, G. 2016. E-Residency: a business platform for Industry 4.0?, Entrepreneurship and Sustainability Issues 3(3): $216-227$. http://dx.doi.org/10.9770/jesi.2016.3.3(1)

Quan-Haase, A., Wellman B., Witte J.C., Hampton K.N. 2002. Capitalizing on the Net: Social Contact, Civic Engagement, and Sense of Community. In Barry Wellman and Carolyne Haythornthwaite (Eds.) The Internet in Everyday Life. Maryland: Blackwell Publising: $289-324$.

Quan-Haase, A., Wellman, B. 2007. From the Computerization Movement to Computerization: A Case Study of a Community of Practice. In Computerization Movements and Technology Diffusion: From Mainframes to Ubiquitous Computing. Medford, NJ: Information Today, 2007.

Samašonok, K.; Išoraitė, M.; Leškienè-Hussey, B. 2016. The internet entrepreneurship: opportunities and problems, Entrepreneurship and Sustainability Issues 3(4): 329-349. http://dx.doi.org/10.9770/jesi.2016.3.4(3)

Sik, E. 2012. Trust, Network Capital, and Informality - Cross-Border Entrepreneurship in the First Two Decades of Post-Communism. Review of Sociology 4: 53-72.

Simpson, L.E. 2005. Community Informatics and Sustainability: Why Social Capital Matters. The Journal of Community Informatics. Vol 1, No 2: 102-121.

Smith C., Smith J.B., Shaw E. 2017. Embracing digital networks: Entrepreneurs' social capital online. Journal of Business Venturing 32(1): 18-34.

Statista. 2017. The Internet Statistics Portal. Social Media \& User-Generated Content. Available on the Internet: https://www.statista. com/markets/424/topic/540/social-media-user-generated-content/

Upwork. 2015. Online Work Report 2014. Available on the Internet: http://elance-odesk.com/online-work-report-global

Urry, J. 2007. Mobilities. Cambridge: Polity Press.

Uslaner, E. M. 2000. Social capital and the net. Communications of the ACM, 43(12): 60-65.

Van Bavel, R., Punie, Y., Tuomi, I. 2004. ICT-enabled Changes in Social Capital. The IPTS Report 85, July 2004. Available on the Internet: http://www.jrc.es/home/report/english/articles /vol85/ict4e856.htm

Wellman, B., Frank, K. 1999. Network Capital in a Multi-Level World: Getting Support from Personal Communities. Social Capital: 
Theory and Research. Chicago: Aldine De Gruyter, 2000: 233-273.

Wellman, B., Haythornthwaite, C. 2002. The Internet in Everyday Life. Oxford, UK: Blackwell Publishing.

White, H., Wellman, B., Nazer, N. 2004. Does Citation Reflect Social Structure: Longitudinal Evidence from the 'Globenet' Interdisciplinary Research Group, Journal of the American Society for Information Science and Technology 55(2): 111-26.

Vladimir MENSHIKOV is Dr.sc.soc., Professor at Daugavpils University. His research interests: sociology of security; regional development; capital theory. He has status of experts of the Latvian Council of Science in the fields of economics and sociology. He is a head of the Centre of Social Research in Daugavpils University, Latvia.

Olga LAVRINENKO is Dr.oec, leading researcher at the Institute of Humanities and Social Sciences of Daugavpils University, Latvia. She has status of experts of the Latvian Council of Science in the field of economics. Her research interests: regional economics, sustainable economic development.

Ludmila SINICA is Mg.oec., PhD student and researcher at the Institute of Humanities and Social Sciences of Daugavpils University, Latvia. Her research interests: ICT; information technologies and economic development; network structure of economic phenomenons.

Anastasiia SIMAKHOVA is Candidate of Economic Science and Professor Assistant of Oles Honchar Dnipro National University, Dnipro, Ukraine. Her research interests: social economy models, global economy social metrics, national economy development, socialization.

Register for an ORCID ID: https://orcid.org/register 